\title{
Ömrünü İlme Vakfetmiş Bir Âlim: Mehmet Fuat Sezgin
}

\section{A Scholar Who Devoted His Life to Science: Mehmet Fuat Sezgin}

\author{
Öğr. Gör. Sadık KOCABAŞ (iD) 1
}

$\ddot{\mathbf{O} z}$

2018 yılı Haziran ayının son günü kaybettiğimiz Mehmet Fuat Sezgin, gerek ülkemiz gerekse İslâm bilim tarihi ve dünya bilim tarihi açısından mümtaz bir âlim ve şahsiyettir. Sezgin, özellikle ömrünün son yıllarında sahip olduğu bilgi, birikim ve tecrübesini Türkiye'ye aktarma gayreti içinde olmuștur. Sezgin'in vefatından bir süre sonra 2019 yılı, Prof. Dr. Fuat Sezgin Yılı olarak kabul edilmiştir. Hem vefatı hem de 2019 yılının ona atfedilmesi ile birlikte ülkemizde yeterince tanınmamış olan bir cevherin özellikle genç kuşaklar için bilinirliğinin artması geç de olsa önemli olacaktır. 2019 yılının kendisine atfedilmesi dolayısıyla birçok bilimsel faaliyet yapılmış ve de yapılması planlanmıştır. Bu çerçevede aynı zamanda bir akademik rol model olan Sezgin'in biyografisinin farklı kişilerce çalışılması yerinde olacaktır. Çünkü muhtemelen Sezgin, dünyada Türkiye'ye kıyasla daha çok tanınan bir ilim adamıdır. Bir bilim tarihi uzmanı olan Sezgin'in hayatı, Bitlis'ten Frankfurt'a uzanmaktadır. Başlıkta da belirtildiği üzere Sezgin hayatını ilim yoluna vakfetmiş bir bilim adamıdır. Sezgin'in biyografilerinde çekirdek aile hayatı hakkında pek bilgi yoktur çünkü kendisi zaten günde 17 saatini çalışmaya ayırmıştır. Bu çalışmada Sezgin'in aile, eğitim, akademik hayatı tarihsel sıralama doğrultusunda ele alınmış, Sezgin'in bilim dünyasına verdiği önemli katkılardan bahsedilmiştir. Yine Sezgin'i başarıya ulaştıran özellikleri, verdiği tavsiyeler, son dönemde Türkiye'ye kazandırdığı eserler, Almanya ile arasındaki hâlen süren dava anlatılmaya çalışılmıştır.

Anahtar Kelimeler: Mehmet Fuat Sezgin, bilim tarihi, İslâm bilim tarihi, biyografi

Makale Türü: Derleme

\begin{abstract}
Mehmet Fuat Sezgin, who we lost on the last day of June 2018, is a distinguished scholar and person for our country both in terms of the history of Islamic Science and World Science. He has striven for transferring his experience and knowledge to whole Turkey especially in the last years of his life. Shortly after Sezgin's death, 2019 was accepted as Professor Fuat Sezgin Year. With both his death and the year 2019 which was attributed to him, it will be important to increase the awareness of this talent who is not well known in our country, especially for the younger generations even if it is late. Since the year 2019 has been attributed to him, many scientific activities have been conducted and planned. Within this framework, it will be appropriate to study Sezgin's biography, which is also an academic role model, by different people. Because Sezgin is a much more recognized scientist in the world when compared to Turkey. The life of Sezgin, who has been an expert in the history of science, extends from Bitlis to Frankfurt. As it is mentioned in the title, Sezgin is a scientist who has devoted his life to science. There is little information about nuclear family life in Sezgin's biographies because he has already devoted 17 hours a day to study. In this study, family, education and academic life of Sezgin are examined in the historical order and important contributions of Sezgin to the world of science are mentioned. Also his features which have led him to success, his advices, his recent works which he has brought to Turkey and the ongoing lawsuit between Germany and him are explained.
\end{abstract}

Keywords: Mehmet Fuat Sezgin, history of science, history of Islamic science, biography

Paper Type: Review

${ }^{1}$ Bartın Üniversitesi, İktisadi ve İdari Bilimler Fakültesi, skocabas@bartin.edu.tr.

Atıf için (to cite): Kocabaş, S. (2019). Ömrünü İlme Vakfetmiş Bir Âlim: Mehmet Fuat Sezgin. Afyon Kocatepe Üniversitesi Sosyal Bilimler Dergisi, 21(Prof. Dr. Fuat Sezgin Özel Sayıs1), 80-93. 


\section{Giriş}

30 Haziran 2018 tarihinde 94 yaşında ahirete irtihal eden büyük âlim Mehmet Fuat Sezgin, aslen Bitlislidir. Dünya çapında bir bilim tarihçisi olan Sezgin, Türkiye'de pek tanınmamaktadır. Şarkiyat alanına yönelmesine ve bir âlim olmasına Hellmut Ritter (öl. 1971) adında bir Alman bilim adamı vesile olmuştur.

Geleneksel eğitim sistemimizde var olan Hoca-Talebe ilişkisi Ritter-Sezgin arasında da görülür. Ritter, zeki ve çalışkan olan Sezgin'in akademik anlamda gelişimi üstlenmiş, onu bir âlim olabilmesi için yönlendirmiş̧tir. Ritter'in yönlendirmesi ile birçok dil öğrenen Sezgin, Ritter ile birlikte İstanbul kütüphanelerinin tozunu yutmuş, birçok yazma eseri onunla incelemiştir ve kendini geliştirmiştir. Bir akrabasının tavsiyesi üzerine seminerine gittiği ve talebesi olmaya karar verdiği Ritter'e, İstanbul Üniversitesi Edebiyat Fakültesi dekanının odasında tesadüfen rastlaması ve bunun sonucunda kayıt günü geçmesine rağmen talebeliğe kabulü, onun için bir şans sayılabilir (Turan, 2012: 13-14).

Ankara Üniversitesi İlahiyat Fakültesi'nde başlayan akademik hayatı bir süre sonra İstanbul'da devam etmiş, 1960 darbesi sonrası Frankfurt'a uzanmıştır. Sezgin Almanya'da bilimler tarihi üzerine gittikçe uzmanlaşmıştır. Burada kurduğu Enstitüde hem araştırmalar yapmış hem de talebe yetiştirmiştir.

Sezgin'in esas gayesi klasik dünya bilim tarihi literatüründe neredeyse yok sayılan İslâm kültür ve medeniyetinin önemli bir yeri olduğunu bilimsel kanıtlarla ispatlamaktır. Nitekim bu uğurda gece gündüz, yaz kış, bayram seyran, hastalık, demeden çalışmış ve yitik hazineyi bulma yolunda ömrünü harcamıştır. Neticede ortaya koyduğu eserler, bunu ispatlamış, Batı uygarlı̆ğının İslâm medeniyetinden beslendiğini göstermiştir. Bunu hem Batıya hem de onlardan daha zor bir şekilde Müslümanlara anlatmaya çalışmış ve çeşitli dirençlerle karşılaşmıştır. Eserlerinde Müslümanlara ait buluşların, eserlerin Batılılarca kaynak gösterilmeden kopyalandığını açık bir şekilde göstermiştir.

Sezgin'e, ömrünün son demlerinde Türk hükümeti tarafından daha önce görmediği şekilde destek verilmiş o da bilgi ve birikimini ülkesi ile paylaşmaya gayret göstermiştir. Son y1llarda bir gelişme olsa da Sezgin hâlâ ülkemizde yeterince tanınmamakta, özellikle gençler tarafından bilinmemektedir. İşte bu çalışma Sezgin'in tanınırlığa bir nebze katkı sağlamak amacıyla ve Sezgin'in hayatından kendimize rol model oluşturabilmek amacıyla yapılmıştır.

\section{Doğumu ve Ailesi}

Mehmet Fuat Sezgin, 24 Ekim 1924'te Bitlis'in Kizılmescid mahallesinde dünyaya gözlerini açmıştır. Babası, Mehmet Mirza Efendi'dir. 1888 yılında Siirt'in Şirvan ilçesine bağlı Kelmih köyünde (bugünkü adı Derinçay) doğan Mirza Efendi'nin babası ise Şeyhi Bey'dir. Şeyhi Bey, Şirvan beylerinden Mir Muhammed'in büyük mahdumudur. Şirvan veya Kufra beyleri olarak bilinen ailenin kökü Eyyubilerin Hasankeyf koluna dayanır. Mirza Efendi kadılık, medrese muallimliği ve müftülük görevlerinde bulunmuş bir şahsiyettir (Hansu, 2019a: 186-189). Fuat Sezgin'in ifadesi ile babası, bir din adamıdır (Fazlıoğlu, 2004: 356). Mirza Efendi 16 Ocak 1943 tarihinde vefat etmiştir ve kabri Ağrı Doğubayazıt’tadır (Hansu, 2019a: 189).

Sezgin'in annesi 1897 Bitlis doğumlu Cemile Feride Hanımdır. Cemile Hanımın babasının adı Faris, annesinin adı ise Şöhret’tir. Cemile Hanımın hayat arkadaşı Mirza Mehmet Efendi 1943'te vefat edince Cemile Hanım kızı Meliha'yla birlikte İstanbul'da bulunan Fuat Sezgin'in yanına taşınmışlardır. Sezgin Almanya'ya gidince de Cemile Hanım, İstanbul Yeşilköy'de oturan kızı Meliha'nın yanında kalmıştır. 06 Mart 1976' da burada vefat etmiştir (Hansu, 2019a: 189-190).

Baba Mirza Efendi ile anne Cemile Hanımın sırasıyla Süphiye, Mehmet Servet, Mehmet Fuat, Meliha ve Refet isimlerinde beş evladı olmuştur. Bunların hepsi Bitlis'te doğmuştur. Fuat Sezgin'den 7 yaş büyük ablası Süphiye Hanım, 1938 yılında Bitlis'in Adilcevaz ilçesinden 
Muhittin Eren'le evlenmiștir. Kendisi vefat etmiștir. Ağabeyi Mehmet Servet Sezgin, 1919'da doğmuştur. 1932'de Ağrı İlkokulundan, 1935'te Bitlis Ortaokulundan, 1938'de İstanbul Erkek Lisesinden ve 1941 'de Ankara Hukuk Fakültesinden mezun olmuştur. Daha sonra hâkimlik mesleğine girmiş ve yurdun farklı yerlerinde mesleğini icra etmiştir. Yine Adalet Bakanlığı bölge müfettişliği görevini üstlenmiştir. Son olarak Ezine hâkimi iken 1951'de istifa ederek Demokrat Parti'den Çanakkale milletvekili olmuştur. 1957'de tekrar Çanakkale milletvekili olarak meclise girmiştir. 1960 darbesinden sonra Başbakan Adnan Menderes'le birlikte Yassıada'da yargılanmış ve 10 sene ağır hapis cezası almıştır. 4,5 sene hapis yattıktan sonra 20.10.1964'te Kayseri Cezaevi'nden şartlı olarak tahliye edilmiş ve sonraki hayatında özel sektörde çalışmıştır. 13 Kasım 2007'de vefat etmiştir (TBMM, 2010: 704 ve Hansu, 2019a: 190). Kız kardeşi Meliha Hanım, 1955 senesinde İstanbul'da Çanakkale doğumlu Yahya Erol'la evlenmiştir. 2011 yılında İstanbul'da vefat eden Meliha hanımın çocuğu olmamıştır. Erkek kardeşi Refet Sezgin ise 1925 doğumludur. 1943 y1lında Erzurum Lisesi'nden, 1950 y1lında ise İstanbul Üniversitesi Hukuk Fakültesinden mezun olmuştur. Çeşitli illerdeki hâkim ve savcılık görevlerinden sonra 1957-1961 yılları arasında Çanakkale'de serbest avukat olarak çalışmıştır. Daha sonra Adalet Partisi'nden politikaya girmiş, 12, 13 ve 14. dönemlerde Çanakkale milletvekilliği yapmıştır. Ayrıca Devlet Bakanı ve Enerji ve Tabii Kaynaklar Bakanı olarak da görev yapmıştır. 12 Eylül darbesinden sonra serbest avukat olarak çalışmış, 11 Aralık 1992'de Ankara'da vefat etmiştir (TBMM, 2010: 914 ve Hansu, 2019a: 190-191).

Fuat Sezgin'in eşi Dr. Ursula Stein, 1939 yılında Frankfurt'ta doğmuş Alman bir Müslümandır. Ursula Hanım, coğrafya ve siyasal bilgiler alanında öğrenciydi ancak sonradan bu tahsilini bırakıp şarkiyat okumaya başlamıştı ve Sezgin'le karşılaşmadan önce Müslüman olmuştu (IBBTAV, 2019). Sezgin'le Frankfurt Müslüman Öğrenciler Cemiyeti'nde tanışmışlardır. Fuat Sezgin, Frankfurt Üniversitesi'ne bilim tarihi doçenti olarak atandıktan bir sene sonra yani 1966'da Ursula Hanımla evlenmiştir. Ursula Hanım, hem Sezgin'in 15 yıl resmi asistanlığını yapmış hem de onun son anına kadar akademik çalışmalarını birlikte gerçekleştirdikleri bir meslektaşı olmuştur. En önemli eseri sayılan Geschichte des Arabischen Schrifttums'un (GAS) (Arap-İslâm Bilimler Tarihi) hazırlanmasında onun büyük yardımcısı olmuştur (Hansu, 2019a: 191). Fuat Sezgin, Ursula Hanımı tanımamış olsaydı 18 ciltlik GAS'ı yazamayacağını beyan etmiş̧tir (URL-1, 2016). Sezgin, eşinden "hayatımın belki de en mühim hadiselerinden biri, hayatımdaki talihli bir tesadüf" diye bahsetmiştir (IBTAV, 2019). Yine Sezgin, eşi ile evlenmesini Allah'ın kendisine verdiği en büyük nimetlerden birisi olarak değerlendirmiş, birlikte mesut bir ömürleri olduğunu ifade etmiştir (URL-2, 2016).

42 yaşında evlenen Fuat Sezgin'in 46 yaşında ilk ve tek çocuğu dünyaya gelmiştir. Sezgin çiftinin Hilal ismini verdikleri kız çocukları 1970'te Frankfurt'ta doğmuştur. Felsefe mezunu olan Hilal Hanım Almanya'da serbest yazar ve gazeteci olarak çalışmaktadır (Hansu, 2019a: 191).

\section{Eğitim Hayatı}

Birçok kaynakta Fuat Sezgin'in, ilkokulu Y1lmaz'dan (2009: 11) alıntılayarak Doğubayazıt'ta tamamladığı yazsa da Hansu'ya göre (2019a: 191) Sezgin, ilkokulu Karaköse'de (Ağrı merkezde) 1931-1936 yılları arasında okumuştur. Ortaokul ve sonrasında lise eğitimini parasız yatılı okulda Erzurum'da 1941-1942 yıllarında bitirmiştir (Hansu, 2019a: 191). Bazı kaynaklarda ise ortaokulu Bitlis'te, liseyi ise Erzurum Lisesi Fen Bölümünde burslu ve yatılı olarak bitirdiği belirtilmiştir (İBTAV, 2019). Sezgin ayrıca bir medreseyi bitirdiğini de söylemiş ama bu konuda detay vermemiştir (Sezgin, 2016: 6).

Fuat Sezgin, önce matematik okurum sonra mühendis olurum diye düşünerek İstanbul'a gelmiştir. Bir akrabasının tavsiyesi üzerine İstanbul Üniversitesi Şarkiyat Araştırmaları Enstitüsünde alanında en bilinir uzmanlardan olan Alman şarkiyatçı Hellmut Ritter tarafından Edebiyat Fakültesinde verilen bir seminere katılmıştır. Bu seminerden o kadar etkilenmiştir ki mühendis olma düşüncesinden vazgeçerek Ritter'in talebesi olmaya karar vermiştir (IBBTAV, 2019). Sezgin, hocası ile olan bu karşılaşmayı hayatının dönüm noktalarından biri olarak 
nitelendirir (URL-2, 2016). Sezgin, kendi deyimiyle o küçük haliyle bile Ritter'in büyük bir adam olduğunu anlar (Y1lmaz, 2009: 11). Seminerden sonraki gün Edebiyat Fakültesine kaydolmaya gitmiştir. Esas amacı Edebiyat Fakültesinden ziyade o büyük âlime talebe olmaktır (Sezgin, 2016: 7). İlk başta günü geçtiği için kendisi kayıt etmek istemezler ancak Sezgin kararlıdır. Dekanın odasına çıkar. O esnada içeri Ritter girer. Dekan, Ritter'e birisinin ona talebe olma arzusunda olduğunu, kendisinin kurtulamadığını söyler. Ritter, Sezgin'i seminerden hatırlar çünkü Ritter zor bir hoca olduğu için seminerlerine katılım çok olmaz (Turan, 2012: 13-14). Ritter evvela Sezgin'i adeta biraz yoklar. Ona kendisinin zor bir hoca olduğunu, zor bir yola girmekte olduğunu, bu işin zengin işi olduğunu Sezgin'e söyler. Sezgin ise fakir bir insan olduğunu, bahsettiği zorlu yola girmeye hazır olduğunu vurgular. Bu kararlılık Ritter'in hoşuna gitmiştir. Dekana, bu çocuğu bana kaydedin der (Sezgin, 2016: 7-8). Neticede Sezgin, İstanbul Üniversitesi Edebiyat Fakültesi Arap ve Fars Filolojisi bölümünde üniversite eğitimine başlamıştır.

Burada Sezgin'in gelişiminde büyük katkısı olan Ritter'den bahsetmek faydalı olacaktır. 1892 Almanya doğumlu olan Hellmut Ritter, 1927-1969 yıllarının tamamında olmasa bile büyük bir kısmında İstanbul'da bulunmuştur. Ritter 32 dil bilen, gününün neredeyse tamamını çalışmayla geçiren, Arapçaya ve Türkiye kütüphanelerine âşık, Sezgin'in ifadesiyle Avrupalı büyük oryantalistlerin en büyügü olan bir hocadır (Turan, 2012: 15 ve Hansu, 2019a: 192-193) Ritter'in, Türkiye'deki yazmaları dünyada en iyi bilen kişi olduğu söylenmiştir (Fazlığlu, 2004: 357). Ritter, 1971'de vefat etmiştir (Sezgin, 2004: 42). Şahin'e göre (2003) Ritter, Nazi zulmüne uğrayıp soluğu İstanbul'da alan Alman kökenli Yahudi akademisyenlerden biridir.

Ritter, Fuat Sezgin'in istidatlı bir genç olduğunu anlamış ve ona matematik dersi almasını salık vermiştir. Hocası, Sezgin'e modern matematiğin temelinde İslâm âlimlerinin kitaplarının olduğunu söylemiş; örnek olarak da Birûnî, Hârezmî, İbnü Yûnis ve İbnü'l-Heysem'in isimlerini zikretmiştir. Onların Batı dünyasındaki en önemli âlimlerle boy ölçüşecek seviyede olduğunu ifade etmiştir. Sezgin bu isimleri duyunca o gün eve gidip zorlu ve uykusuz bir gece geçirdiğini söylemiştir (Sezgin, 2004: 21). Çünkü Sezgin, gerek ilkokulda gerekse lisede hocalarından eskiden Müslüman bilginlerin dünyanın öküzün boynuzları üstünde durduğuna inandığını ve depremlerin meydana gelişinin öküzün başını sallamasıyla izah ettiklerini duymuştur (Kenan, 2003: 78 ve Yılmaz, 2009: 13). Artık Sezgin, Ritter'den daha çok bilgi öğrenmek istemektedir.

Ritter, Sezgin ile çalışmaya başladıktan iki gün sonra ona günde kaç saat çalıştığını sormuş, 13-14 saat cevabını alınca bu çalışmayla âlim olamazsın, eğer âlim olmak istiyorsan çalışma süreni artırman gerekir demiştir. Sezgin de bu tavsiye üzerine kademeli bir şekilde çalışma saatlerini artırmış ve günde 17 saat çalışır hâle gelmiştir. Sezgin, bu temponun 70 yaşına kadar sürdüğünü sonra tembelleştiğini söylese de 70'inden sonra yine günde 13-14 saat çalışmaya devam etmiştir (Yılmaz, 2009: 13 ve Sezgin, 2016: 9).

Ritter'in üzerinde durduğu hususlardan biri de dil öğrenmektir. Sezgin'den de dil öğrenmesini istemiştir. Sezgin, üniversite 1. sınıfta Arapça, Farsça, Latince ve Yunanca öğrenmeye başlamıştır. Ancak Ritter, Sezgin'in Arapçayı öğrenme hızını beğenmemiştir. $\mathrm{O}$ dönemde yani 1943'te 2. Dünya Savaş1 sebebiyle Almanlar Bulgaristan'a kadar gelince Türkiye'de okullar 6 ay kadar tatil edilmiştir. Ritter, Sezgin'e bu 6 ayda Arapçayı öğrenmesini söylemiştir. Ritter'in bu tavsiyesi Sezgin'e tesir etmiş ve bu süre zarfında babasından kalma 30 ciltlik Taberi Tefsirini Türkçe tefsirlerle karşılaştırarak okumaya başlamıştır. İlk başlarda zorlansa da yavaş yavaş Arapçayı sökmeye başlamıştır. Neredeyse 6 ay evden hiç çıkmadan günde 17 saat çalışarak tefsir kitabını adeta gazete okur gibi süratli okumaya ve anlamaya başlamıştır. Okullar açılınca Ritter onun bu şekilde muvaffak olduğunu görünce çok sevinmiş ve Sezgin'i orada bulunan Alman Yahudi profesörlere övmüştür. Daha sonra diğer dilleri de bu kadar hızlı öğrenmeni istiyorum diye onu motive etmiştir (Turan, 2012: 15 ve Sezgin, 2016: 9). Fuat Sezgin, yabancı dil öğrenme konusundaki başarısında babasının payı olduğuna inanmaktadır. Çünkü Sezgin ilkokul 3. sınıfta iken okullardan Türkçe gramer bilgisi dersi kaldırılmıştır. Bunun üzerine babası Mirza Efendi, Fuat Sezgin'e Sarf-1 Türki (Türkçe gramer bilgisi) öğretmiş̧tir. Fuat Sezgin, aynı zamanda babasından öğrendiği gramer bilgisinin kendisine bilimler tarihçisi olma 
yolunu açtığına inanır. Çünkü Sezgin'e göre bir kimse kendi anadilinin gramerini tam olarak bilmiyorsa, yabancı dili de öğrenmesi çok zor olacaktır (Turan, 2012: 37 ve Dere, 2018b: 47).

Hellmut Ritter, Fuat Sezgin'i azimli, çalışkan ve kendisine olan bağlı gördüğg̈ için çalışmalarında onu da yanına almıştır. Böylece kütüphanelerdeki İslâm bilim tarihi ile ilgili yazma eserleri ve araştırmaları birlikte incelemeye başlamışlardır. Sezgin, bu incelemelerle birlikte İslâm bilim tarihi çalışmalarındaki eksikleri daha net görme imkânı bulmuştur. Bu alanda Ritter'in de hocası olan Carl Brockelmann'in 5 ciltlik eseri Geschichte der Arabischen Litteratur'u (Arapça Elyazmaları Literatürü) (GAL) okudukça bu eserin bazı eksikliklerini fark ettiler. (İBTAV, 2019). Ritter, bu konuda Sezgin'e birisinin bu kitabın eksikliklerinin tamamlaması gerektiğini söylemiştir. Bu sözleri duyan Sezgin, hocasının kendisinden bunu beklediğini düşünerek eserin eksikliklerini tamamlamaya kendince karar vermiştir ve kaynakları, malzemeleri toplamaya başlamıştır (Turan, 2012: 70). Bu süreç uzun olacaktır.

Sezgin, 1947 tarihinde İstanbul Üniversitesi Fars ve Arap Filolojisi bölümünden lisans mezunu olmuştur (Karakaş, 2015: 89). Mezuniyet tezini “Bedî’ İlminin Tekâmülü ve İstanbul'da Bulunan Bedîiyyat Yazmalar Kataloğu" adıyla Arap-Fars filolojisinden yapmıştır (Hansu, 2019a: 192). Ekim 1947'de doktoraya başvurarak Ritter'in danışmanlığında çalışmalarına devam etmiş̧tir. Doktora tez çalışmasını, Arap dili ve tefsir âlimi Ebû Ubeyde Ma'mer İbn el-Musenna et-Teymî'nin Mecâzu'1-Kur'ân adlı tefsiri üzerine yapmıştır. Bu tezin konusu ise Kur'an-1 Kerim'de gerçek anlamı dışında kullanılan mecazî ifadelerdir. Doktora tezini 1950'de bitirmiştir. Fuat Sezgin bu tarihlerde aynı zamanda İstanbul Üniversitesi Kütüphanesi'nde memur olarak çalışmaktadır (IBBTAV, 2019). Bu memuriyetinden önce de 15 ay İstanbul Müftülüğünde kâtip olarak görev yapmıştır (Hansu, 2019a: 197). Sezgin'in biyografilerinde genellikle kâtipliği ile bilgi verilmemiştir.

\section{Sezgin'in Akademi Serüveni}

Fuat Sezgin'in akademik hayatını Türkiye ayağı ve Almanya ayağı olmak üzere ikiye ayırmak gerekir. 1950-1960 arasında Ankara ve İstanbul Üniversitelerinde görev yapmış 1960 ’tan sonra Almanya'ya gitmek zorunda kalmıştır.

\subsection{Türkiye'deki Akademik Hayatı}

Sezgin, akademik camiaya Ekim 1950'de bir sene önce öğretime başlayan Ankara Üniversitesi İlahiyat Fakültesinde bugün yaklaşık olarak Temel İslâm Bilimleri bölümünün alanlarını kapsayan Doğmatik İlimler Kürsüsünün ilk asistan adayı olarak girmiştir (Dere, 2018a: 224). Sezgin'in biyografilerinde ilginç bir şekilde Ankara Üniversitesi yıllarına pek değinilmediği görülmektedir (Hıdır, 2018).

Sezgin, askerliğini yedek subay olarak yapmak üzere Mayıs 1951'de Ankara Üniversitesindeki asistanlık görevinden ayrılmıştır. Askerliğini bitirip terhis olduktan yaklaşık bir sene sonra Nisan 1952'de tekrar Ankara Üniversitesine başvurmuştur. O dönemde askere giden akademik personelin üniversite ile ilişiği kesildiği için tekrar başvuru yapmak durumunda kalmıştır. Başvurusu üzerine tefsir dersi asistanı olarak atanmıştır (Dere, 2018a: 231-232).

Fuat Sezgin, doktorada ele aldığı Mecâzu'1-Kur'ân'1 yayımlamak istemektedir. Arapça yayın konusunda o dönemde akla ilk Kahire gelmektedir. Ankara Üniversitesinden 22 Temmuz22 Ağustos 1952 tarihleri arasında bir ay yıllık izin almıştır. Ancak izin bitiminden yaklaşık bir buçuk ay sonrasında işe başlamadığı için hakkında işlem başlatılmak üzere fakülte, rektörlüğe yazı yazmıştır. Daha sonra Sezgin'in rektörlüğe iki aylık sağlık raporu gönderdiği anlaşılmıştır (Dere, 2018a: 233-235).

Sezgin, 30.10.1950 tarihinde göreve başladığı Ankara İlahiyattan tekrar İstanbul'a dönmek üzere 28.02.1953 tarihinde ayrılmıştır. İstanbul'a dönmek istemesinin muhtemelen başlıca gerekçeleri, hocası Ritter'in İstanbul'da olması, oradaki ilmi ortama aşinalığı, yazma 
eserler konusunda İstanbul'un zengin olması, yetiştiği üniversiteye gidecek olması olarak sayllabilir (Dere, 2018a: 236-237).

Sezgin, 1953’te İstanbul'da Umumi Türk Tarihi Enstitüsünde asistan olarak vazifeye başlamıştır. Buradan daha sonra İslâm Tetkikleri Enstitüsüne geçecektir. Doktora tezi için araştırmalar yaptığı esnada, Buhârî'nin hadis kitabından bazı kısımların Mecâzu'l-Kur'ân'dan alındığını görmüştür. Buhârî'nin yazılı kaynakları kullanmış olması, hadis kitaplarının sadece sözlü geleneğe dayandığına dair müsteşriklerin iddialarının hatalı olduğunu ortaya koymuştur. Fuat Sezgin, Buhârî'nin Kaynakları Hakkında Araştırmalar adını verdiği doçentlik tezini 1956'da yayımlamıştır (IBBTAV, 2019). Sezgin, bu tezi ile hadis kaynăgı olarak İslâm kültüründe önemli bir yere sahip olan Buhârî'nin topladığı hadislerde bilinenin aksine sözlü kaynaklara değil, İslâm'ın erken dönemine hatta miladi 7. yüzyıla yani Eshab-1 Kiram ve Tabiin'in yaşadığı asra kadar giden yazılı kaynaklara dayandığını ortaya koymuştur. Bu tez, Avrupalı şarkiyatçılarca hâlâ tartışılmaktadır (Karakaş, 2015: 89).

Asistanlıktan doçentliğe geçen Sezgin, kimi kaynaklara göre (IBTAV, 2019) 1957-1958 arasında, kimi kaynaklara göre ise (Tuğ, 2018) 1958-1960 arasında bilim insanlarını destekleyen Almanya merkezli Alexander von Humboldt Vakfi bursunu kazanıp bilimsel araştırmalar yapmak ve Almancasını ilerletmek niyetiyle Almanya'ya gitmiştir.

Tarihler 27 Mayıs 1960'1 gösterdiğinde Türkiye'de askeri darbe gerçekleşmiştir. Darbe neticesinde kurulan hükümet, üniversitelerde görev yapan 147 akademisyenin görevine son veren listeyi hazırlamıştır. 147'likler olarak bilinen bu listede Fuat Sezgin de vardır. Sezgin, bu listede olduğunu gazetelerden öğrenmiştir (Turan, 2012: 63). Oğur'a göre (2018) Fuat Sezgin, zararlı profesörler diye adlandırılan listeye, Demokrat Parti Çanakkale milletvekili olan ağabeyi Servet Sezgin yüzünden girmiştir. Ağabey Sezgin, Yassıada'da yargılanmıştır. Suçlama, "Çanakkale’ye gelen CHP'lileri taşıyan bir geminin iskeleye çıkmasına izin vermemek ve halkı birbirine düşürmeye çalışmak”tır. Savcı Servet Sezgin'in idamını istemiştir. Servet Sezgin, bu yargılama neticesinde 10 yıl ağır hapis cezası almıştır. Ancak 4 yıl sonra bir afla cezaevindeki son siyasi mahkûm olarak çıkmıştır.

Gazetede kendi ismini de gören Sezgin, Amerika ve Almanya'daki arkadaşlarına Türkiye'den ayrılmak zorunda olduğunu, kendisi için oralarda bir iş imkânı olup olmadığını soran mektuplar yazmıştır. Yaklaşık 2 hafta içinde 3 üniversiteden davet gelmiştir. Sezgin, Frankfurt Goethe Üniversitesini tercih etmiştir. Çünkü Amerika'ya gidip İstanbul'dan ve doğudan çok uzaklaşmak istememektedir ve dünyanın tek Bilimler Enstitüsü Frankfurt'tadır. Sezgin, 1961'de valizinin içine biraz kıyafet ve bolca araştırma notlarını içeren fiş (20-25 bin civarı) alıp yola çıkmıştır (Turan, 2012: 65).

\subsection{Almanya'daki Akademik Hayatı}

36 yaşında genç bir doçent olarak istemeden de olsa Türkiye'den ayrılan Sezgin, bilimsel çalışmalarına Frankfurt'ta devam etmiştir. 1963'e kadar Goethe Üniversitesi ve Marburg Üniversitesinde misafir doçent olarak dersler vermiştir. Tabii ilimler alanında ikinci bir doktora ve doçentlik çalışmasını yapmış, doçentliğin hemen ardından 1966 senesinde Frankfurt Üniversitesi'nde bilimler tarihi profesörü olmuştur (Karakaş, 2015: 74-75).

1967'de kısaca GAS diye bilinen Geschichte des arabischen Schrifttums (Arap-İslâm Bilimleri Tarihi) adlı eserinin ilk cildini yayınlamıştır. Bu cildin içeriğindeki konular, Kur'an bilimleri, hadis, tarih, fikıh, kelam ve tasavvuftur. Yukarıda zikredildiği gibi bu kitabın ortaya çıkmasında Ursula Hanımın da önemli bir payı olmuştur. Yine yukarıda bahsedildiği üzere Sezgin, bu eserle ilgili kaynaklarını lisans öğrencisi iken Carl Brockelmann'ın eseri olan GAL'e bir zeyl yazma niyetiyle toplamaya başlamıştır. İslâm bilim tarihi alanında, çalışmalarına başlaması ile Avrupalıların bir komite ile bu alanda yeni bir çalışmaya girmeleri aynı zaman dilimine denk gelmiştir. Ancak bu komite, Sezgin'in bu alanda çalışacağını öğrendiğinde önce kendisi ile alay etmiş, ardından ilk kitap çıktığında komite kendisini lağvetmiştir (Korkmaz, 2009: 
86). Hem tek kişinin hem de bir Müslüman Türk'ün böyle çalışma yapması komitedeki kişileri hayrete düşürmüştür. Söz konusu eserin ilk cildi Arap-İslâm Bilimleri Tarihi I ismiyle Türkçeye çevrilmiş ve Prof. Dr. Fuat Sezgin İslâm Bilim Tarihi Araştırmaları Vakfı tarafından 2015 yılında yayımlanmıştır.

GAL’e bir zeyl niyetinden bütün yazma eserleri tarayarak müstakil bir esere dönme fikrine Ritter, bunu kimsenin yapamayacağı yönünde fikir beyan etmiştir. Ancak Sezgin, inanmış, çalışmış ve bu işin de üstesinden gelmiştir. Bu eseri İstanbul'daki hocası Ritter'e göndermiştir. Aradan zaman geçtikten sonra Ritter cevabında böyle bir çalışmanın daha önce yapılmadığını ve bundan sonra da yapılmasının zor olduğunu ifade edip Sezgin'i tebrik etmiştir (Hıdır, 2018). Bu övgü ve tebrik Sezgin'in motivasyonunu artırmıştır.

Fuat Sezgin, kitabını yazarken İslâm tarihi çalışmalarının adeta tesadüfe bağlı olduğunu tespit etmiştir. Eğer Avrupa'da insaflı büyük âlimler çıkarsa onlar Müslümanların keşiflerini insaflı bir şekilde ortaya koymuştur. Ama onlar geçince her şey öylece kalmıştır. Dolayısıyla bu çalışmaların bir sürekliliği olmadığını görmüştür. Sezgin bilim tarihinin çok geniş olarak ele alınması gerektiğine inanmıştır. Bunun da enstitü gibi bir kurum çatısı altında yapılması zarurettir. Böyle bir kurum için maddi desteğin olması gerekir. Sezgin'in aklından bu düşünceler geçerken kendisi 1978'de Kral Faysal İslami İlimler Ödülünü kazanmıştır. Bu uluslararası bir mükâfattır ve Sezgin bu durumu kurmak istediği enstitüye maddi destek sağlanması için firsat olarak görmüştür. Ödül töreninde birçok devlet adamı ile tanışma imkânı elde etmiştir. Sezgin, enstitüye maddi destek verecek bir vakıf kurmayı kafasına koymuştur. O eğer bir şeyi kafasına koyarsa onu mutlaka gerçekleştirir. Neticede iki sene süren müthiş bir gayret ile dekanın, rektörün, Kuveyt devletinin destekleri alınmış ve vakıf Sezgin tarafından kurulmuştur. Bir sonraki aşama vakfın gelirlerini enstitünün giderlerini karşılayacak şekilde artırmaktır. Zor da olsa bunu da başarır (Fazlıoğlu, 2004: 360-362). Nihayetinde 1982 y1lında Goethe Üniversitesi'ne bağlı olan Arapİslâm Bilimler Tarihi Enstitüsünü (Institut für Geschichte der Arabisch-Islamischen Wissenschaften) kurmuştur (İBTAV, 2018).

Sezgin, enstitünün hedeflerini İslâm ilimler tarihini geniş çaplı araştırmak, tanıtmak ve genel bilimler tarihinde Müslümanların iyi tanınmayan yerlerini ve yanlış olarak koyulan hükümleri düzeltebilmek olarak ifade etmiştir (IBBTAV, 2018). Tabii enstitünün faydalı olabilmesi, bu hedefine ulaşabilmesi için maddi desteğin yanında insan kaynağına da ihtiyaç vardır. Sezgin'in ifadesi ile o zaman Avrupa'da bu işe inanan yoktu, Arap dünyasında ise bu işten anlayan yoktu. Fakat kendisi üstün bir gayret ile adeta gece gündüz çalışarak enstitüyü dünya çapında bilinir bir seviyeye yükseltmiştir (Fazlıoğlu, 2004: 362).

Sezgin'in projelerinden biri de İslâm Bilim Tarihi Müzesidir. Bu müzeye Müslüman âlimlerin yaptığ 1 aletlerin numunelerini ortaya koymayı arzulamıştır. Bu konuda yıllar önce çalışan ve İslâm bilim aletlerini kitaplardan modeller hâlinde insanlara tanıtmak isteyen Eilhard Wiedemann adında bir Alman fizikçi olmuştur. Wiedemann 1900'de başladığ 1 işte 28 yılda yaklaşık olarak 5 tane aletin modelini yapabilmiştir. Sezgin de 30 alet yapma hedefine bile şüpheyle yaklaşmış, bir müze olmasa bile bir oda dolar mı düşüncesi ile çalışmalarını başlatmıştır. $\mathrm{Bu}$ çalışmalar neticesinde kendisinin bile hayal edemediği bir başarı sağlanmış, Frankfurt'ta kurduğu İslâm Bilim Tarihi müzesinde 800 'den fazla aletin modeli yapılmıştır. Aynı binada Bilimler Tarihi Kütüphanesi bulunmaktadır. Burada hayatı boyunca dünyanın her yerinden büyük bir özenle, meşakkatlere katlanarak aldığ 45 bin cilt kitap ve 10 bin mikrofilm vardır. $\mathrm{Bu}$ kitaplardan bazıları, orijinal tek nüsha olma özelliğini taşır. Bilimler Tarihi Kütüphanesi, İslâm bilimler tarihi açısından dünyada tek olma özelliğine sahip bir uzmanlık kütüphanesidir (URL-3, 2017: 2). 


\section{Türkiye’de Müze, Vakıf, Enstitü ve Kütüphane Kurma Çalışmaları}

Fuat Sezgin, Almanya'da kurduğu İslâm Bilim Tarihi Müzesinin bir benzerini kendi vatanında, özellikle kendi milletinin hizmetine sunmak üzere İstanbul'da kurmaya karar vermiştir. Hedefi, Türklerin kendi medeniyetlerinin bu olağanüstü başarılarını ve Müslüman âlimlerin ilimler tarihine katkılarını daha elle tutulur bir şekilde görmelerini sağlamaktır. Aynı zamanda İslâm medeniyetinin büyüklüğünü bu müze sayesinde turistlerin de görmesini hedeflemiştir. Müzenin yerini yani Gülhane Parkındaki Has Ahırlar Binasını tesadüfen gördüğünü söyleyen Sezgin, bu binayı görünce müzeyle ilgili rüyalarının gerçekleşeceğine inanmıştır. Dönemin İstanbul Büyükş̧ehir Belediye Başkanı Kadir Topbaş, belediyenin binayı müze olarak verebileceğini söylemiştir. Sezgin'in vurguladığına göre başta dönemin Başbakanı Recep Tayyip Erdoğan olmak üzere hükümet müzenin kurulması için gerekli kolaylıkları göstermiştir. Tahsis edilen bina devlet marifetiyle tadilattan geçirilmiştir. Sezgin, ilerlemiş yaşına rağmen müzenin yapım aşamasında Frankfurt-İstanbul arasında adeta mekik dokumuştur. İslâm Bilim ve Teknoloji Tarihi Müzesi'nin aç1lışı 25 Mayıs 2008'de gerçekleşmiştir. Aletlerin yüzde 80 'i Frankfurt'taki enstitüden hediye olarak gelmiştir. Yüzde yirmisi ise devlet finansmanı ile temin edilmiştir. Şu anda müzede 700'ün üzerinde eser sergilenmektedir (Turan, 2012: 87-88). Müzede geometri, gemicilik, astronomi, tıp, coğrafya, zaman ölçümü, optik, kimya, fizik, mimari, mineraloji, teknik ve harp tekniği gibi alanlarda sergilenen eserler, İslâm bilimlerinin buluşlarını göstermekle birlikte bu keşif ve buluşların değişik yollardan Avrupa'ya götürülüp orada kabul gördüğ̈̈nü ve özümsendiğini görsel bir şekilde ziyaretçilerine sunmaktadır (URL-4, 2019)

Müzenin faaliyetlerini desteklemek amaciyla 2010 yılında Prof. Dr. Fuat Sezgin İslâm Bilim Tarihi Araştırmaları Vakfı kurulmuştur. Ayrıca yine Fuat Sezgin'in öncülügüüle 2013 yılında Fatih Sultan Mehmet Vakıf Üniversitesi bünyesinde lisans, yüksek lisans ve doktora alanlarında eğitim veren Bilim Tarihi Bölümü ve Prof. Dr. Fuat Sezgin İslâm Bilim Tarihi Enstitüsü açılmıştır. Fuat Sezgin'in bilim tarihi alanında Türkiye'ye yaptığı bir hizmet de Prof. Dr. Fuat Sezgin ve Dr. Ursula Sezgin Bilimler Tarihi Kütüphanesi'ni kurmak olmuştur. Fuat Sezgin'in bütün bu çalışmaları sırasında Ursula Hanım da önemli destekler vermiştir. Gülhane Parkı içerisinde kurulan kütüphanede 30 bine yakın kitap bulunmaktadır (IBTAV, 2019).

\section{Aldığı Ödüller, Eserleri ve Bilim Dünyasına Katkıları}

\subsection{Aldığı Ödüller}

Beynelmilel çeşitli akademilerde üyeliği olan Sezgin, çok sayıda önemli nişan ve ödüle layık görülmüştür. Bunlardan bazıları Kahire Arap Dili Akademisi, Şam Arap Dili Akademisi, Fas Rabat Kraliyet Akademisi, Bağdat Arap Dili Akademisi, Türkiye Bilimler Akademisi şeref üyeliğidir. Ayrıca Frankfurt am Main Goethe Plaketi, Almanya Birinci Derece Federal Hizmet Madalyası, Almanya Üstün Hizmet Madalyası, İran İslami Bilimler Kitap Ödülü ve T.C. Cumhurbaşkanlığı Kültür ve Sanat Büyük Ödülü gibi ödüllerin sahibidir (URL-5, 2018).

Fuat Sezgin, kendisine verilen Hessen Kültür Ödülünü ise reddetmiştir. Ret gerekçesi olarak; Gazze katliamında İsrail yanlısı açıklamalarıyla tepki çeken Alman Yahudileri Birliği Başkanı Salomon Korn ile aynı ödülü alamayacağını, siyaset anlayışının ve kültür yapısının buna müsaade etmediğini sunmuş ve herkesi çok şaşırtmıştır (Macit, 2018).

Sezgin'in öncülüğ̈̈nde İstanbul'da kurulan ve yukarıda zikredilen müze de üstün nitelikli eser ve ortaya konan özgün çalışmalardan dolayı kurum kategorisinde Kültür ve Turizm Bakanlığı 2016 Özel Ödülünü kazanmıştır (URL-5, 2018).

Ayrıca Sezgin'e Türkiye'de Erzurum Atatürk Üniversitesi, Isparta Süleyman Demirel Üniversitesi, Kayseri Erciyes Üniversitesi ve İstanbul Üniversitesi tarafindan fahri doktora unvanı verilmiştir (URL-5, 2018). Sezgin, bu üniversitelere gittiğinde öğrencilere ve akademik camiaya uyarıcı ve uyandırıcı niteliklerde konferanslar vermiş ve söyleşilerde bulunmuştur. $\mathrm{Bu}$ konuşmalarında kimi zaman belirli bir konudan bahsetmiş, kimi zaman da hayatını, çalışma temposunu anlatmıştır. Müslümanların, bilim tarihine önemli katkıları olduğunu, Batının İslâm 
medeniyetini yok sayan anlayışının yanlış olduğunu vurgulamıştır. Anlattıkları ile gençleri daha çok çalışmaya, okumaya, dil öğrenmeye sevk etmiş, İslâm medeniyetinin fertlerini aşağıllk duygusundan kurtarmaya gayret göstermiştir.

2019 yılının Prof. Dr. Fuat Sezgin Yılı olarak kabul edilmesi de kendisinin ve eserlerinin yaşatılması bakımından bir ödül olarak addedilebilir.

\subsection{Eserleri ve Bilim Dünyasına Katkıları}

Hayatını ilme vakfeden Sezgin, ömrü boyunca birçok kitap yazmış, tercümeler yapmış, editörlüğünde yayınlar yapmıştır. Günümüzde Sezgin adına basılan 1300 civarında eser bulunmaktadır ki bu gerçekten önemli bir ilmi mirastır (Karakaş, 2015: 93).

Eserleri arasında en dikkat çekeni, yukarıda da yazım süreci ve ilk cildinden bahsedilen kısaca GAS diye bilinen Arap-İslâm Bilimleri Tarihi kitabıdır. Toplam 17 cilt ve 9324 sayfadan oluşan bir başyapıttır. Bu ciltlerde işlenen konular şunlardır (Tali, 2019: 13): Kıraat, Kur'an ilimleri, hadis, tarih, fikıh, kelam, tasavvuf (1. cilt), şiir (2. cilt), tıp, eczacılık, zooloji, veterinerlik (3. cilt), kimya, botanik, ziraat (4. cilt), matematik (5. cilt), astronomi (6. cilt), astroloji, meteoroloji (7. cilt), sözlük çalışmaları (8. cilt), gramer (9. cilt), matematiksel coğrafya ve haritacılık (10-11-12-13. ciltler), beşeri coğrafya (14-15. ciltler), hitabet ve edebî teori, şiir, antolojiler, edebi nesir (16. cilt), edeb ve eğitim (17. cilt).

Sezgin bahsedilen eseri 300 bin yazma eseri inceleyerek ve uzun y1llar çalışarak ortaya çıkarmıştır. Yeri gelmiş yazdığı konuyla alakalı bilgi sahibi olmaya uğraşmış, yeri gelmiş yeni dil veya diller öğrenmiştir (Hıdır, 2018). Mesela coğrafya konusunu yazmaya 28 senesini vermiştir. Bu süre zarfında bildiği dillerin yeterli olmadığını anlayınca 53 yaşından sonra Rusça, 60 yaşından sonra da Portekizce öğrenmiştir (Kenan, 2003: 78). 18. cildi yazmaya ise ömrü yetmemiştir.

Mecaz'ül Kur'an, Buhari'nin Kaynakları, İslâm'da Bilim ve Teknik (5 cilt), Amerika Kıtasının Müslüman Denizciler Tarafından Kolomb Öncesi Keşfi, Tanınmayan Büyük Çağ, İslâm Bilimler Tarihi Üzerine Konferanslar gibi eserleri de vardır.

$\mathrm{Bu}$ eserler haricinde Sezgin'in bilim dünyasına bir diğer önemli katkısı 19. ve 20 yüzyıllarda farklı dillerde yayınlamış olan temin edilmesi oldukça zor olan yüzlerce makaleyi farklı alan ve konulara göre tasnif ederek ciltler halinde yayınlamış olmasıdır (Şen, 2018).

Fuat Sezgin'in bir de tıpkıbasımları var ki, bunlar da ulaşılması zor olan yazmaların tıpkıbasımlarından oluşmaktadır. Artık günümüzde yazmaların dijital kopyalarına ulaşmak nispeten kolay olsa da bundan 10 sene öncesine kadar bir yazmanın görsellerine ulaşmak çok zordu. Bu anlamda Sezgin'in tıpkıbasım serisi de bilim dünyasına büyük bir hizmetti (Şen, 2018).

Sezgin'in ilim camiasına yaptığı bir başka katkı da yukarıda bahsedilen Müslüman bilginlerin buluşlarının modellerini yaptırması ve bunların müzelerde sergilenmesidir. $\mathrm{Bu}$ koleksiyonlar İslâm medeniyetinde bilim geleneğinin zenginliğini etkileyici ve ikna edici bir şekilde ortaya koymuştur (Şen, 2018).

Sezgin'in eserlerinde bilim dünyasında aslında Müslümanların keşiflerinin veya yazdığı eserlerin Batılılar tarafından tercüme edildiği ve Müslümanların isminin gizlendiği ortaya çıkarılmıştır. Mesela hazırladığı Islamic Geography adlı eserde Sezgin, 18. yüzyılda Avrupa'daki eski dünya haritalarının aslında İslâm coğrafyacılarının çalışmalarından türetildiğini ve pek çoğunun doğrudan kopya olduğunu ortaya çıkarmıştır (Kenan, 2003: 78).

Sezgin'e göre (2004: 37-38) Avrupa'da yaklaşık 17. yüzyıla kadar kaynak anma kavramı yok denecek kadar azdı. Birçok Arapça kitap tercümesi ya Avrupalı veya Yunanlı bilginlerin adı altında yüzyıllarca yayınlandı ve kullanıldı. Kaynak adı verme büyük Yunan bilginlerinde de yok gibiydi. Kaynakları belirli bir sistematik içinde vermek, geçmiş kuşakların emeklerini anmak 
ilkesi, İslâm kültür dünyasının karakteristik özelliklerindendir. Bu gerçek, bilimler tarihinde 1skalanmaktadır.

Yine Sezgin (2004: 38) Tunuslu ve tıptan anlayan bir tacirin Müslümanların yazdığ 25 tane önemli tıp kitabını rahiplere Latince olarak çevirttiğini ve bu kitaplara ya kendi adını ya da eski Yunan otoritelerinin adını verdiğini ortaya koymuştur.

Sezgin, Müslümanların kendi kültürlerinin bilim tarihindeki yerini bilmediğini ya da bu konuda yanlış bilgi sahibi olduğunu görmüş ve neredeyse ömrünü bu bilgisizliği ortadan kaldırmaya adamıştır. Ona göre Müslümanlarda ve Türklerde bir aşağılık duygusu vardır. Birçok Türk aydını, Batı dünyasına ulaşabilmenin çaresini Türk toplumunu dinden koparmakta bulmuştur. Ancak kendisi 60 yıllık çalışması sırasında her gün biraz daha fazla İslâm uygarlığını tanımanın ve tanıtmanın Batı dünyasına ulaşma davası bakımından tek yol olduğuna inanmıştır (Sezgin, 2004: 22).

Fuat Sezgin, 26 sene süren araştırmaları esnasında Amerika'yı Kristof Kolomb'dan çok önce Müslümanların keşfettiğini, Vasco da Gama'nın Müslümanlara ait haritalarla Hindistan'a ulaştığını belgeleriyle ispatlamıştır (Yardım, 2018).

\section{6. Şahsiyeti Hakkında Bilgiler ve Tavsiyeleri}

Sezgin'in belki de en önemli özelliği zekâsının yanında çok çalışmasıdır. Hocasının tavsiyesi ile 70 yaşına kadar 17 saat çalıştığını, 70'inden sonra da 13-14 saat çalıştığı yukarıda vurgulandı. Başarısının sırlarından biri muhakkak bu özelliğidir. Sezgin yaptığı söyleşilerde de Müslümanların ve Türklerin çok çalışması gerektiğini ifade etmiştir. Kendisinin bu tempoda kimi zaman yorulduğunu ve dinlenmek istediğini ancak sonra vakit geçiyor diyerek kendisine telkinde bulunup çalışmaya, yazmaya, okumaya geri döndügünü ifade etmiştir. Kendisini ilme vakfetmiştir. Bu noktada Türk milletine okuyan, yazan, düşünen bir yapıda olmayı tavsiye etmiş̧tir (Demirci, 2018). Hastalansa da çalışmalarına devam etmiştir. İstikrarlı çalışmasına halel gelmesin diye evlendiğinde düğün bile yapmamıştır (Dere, 2018b: 45). Yoğun çalışma temposu sebebiyle Almanya'da onca sene oturduğu kasabayı gündüz gözüyle hiç görememiştir (Kar, 2018).

Bir diğer önemli özelliği çok dil bilmesi ve dil öğrenmeye yatkınlığıdır. İnsanlara da dil öğrenmeyi tavsiye etmiş, bunun için anadilimizdeki dil bilgisi kuralları tam olarak öğrenmekle işe başlanmasını tavsiye etmiştir. Dilin masa başında çok çalışarak öğrenileceğini düşünmektedir.

Sezgin'in bir başka özelliği multi-disipliner bir âlim olmasıdır. Matematik, coğrafya, tarih, bilim tarihi, edebiyat gibi farklı alanlarda çalışmaları olmuştur (Hıdır, 2018).

Kendisi haksızlığın karşısında duran, mazlumların yanında yer alan, onların dertleriyle dertlenen, duyarlı ve şuurlu bir şahsiyettir. İnandığını, kafasına koyduğunu yapmaya gayret eden bir yapısı vardır. Gündelik siyasetten, polemik ve demagojiden uzak duran mütevazı bilim adamı kişiliği vardır. Bilimlerin temeli İslâm bilimleridir felsefesini kendisine düstur edinmiştir ve bu noktada sabırla çalışmıştır (Hıdır, 2018).

Başına kötü bir şey gelse de hayata küsmeyen affedici bir yapısı vardır. 147'ler listesinde üniversiteden atılsa da bunu çok dert etmemiştir. Kaderin bir tezahürü olarak, olması gerektiği için olmuştur diyerek teslimiyet göstermiş, ülkesine ve devletine küsmemiştir (Dere, 2018b: 45).

Dürüstlük, işin ehli olmak, üstlendiği işin hakkını vermek, yalan söylememek, dini ve dinî değerleri suiistimal etmemek, tembel olmamak, egoist olmamak onun için önemli hasletlerdendi. Sade bir hayatı vardı. Tevekkül ve vicdan sahibi idi. Gördüğü yanlışları söylemekten çekinmezdi (Dere, 2018b: 46-47).

Fuat Sezgin, vejetaryendi (Yolcu, 2018: 38) ve bilgisayar kullanmazdı (Özsoy, 2018). Celal Şengör'e göre Sezgin, 5 yaşındaki bir çocuk gibi meraka sahipti. Okuduklarını unutmayacak müthiş bir zekâsı vardı. Bitmek tükenmek bilmeyen bir enerjisi vardı (Sezgin, 2004: 12). 
Kuveyt Üniversitesinde verdiği konferans sonrası kendisinden tavsiye isteyen gence dünyanın nimetlerinden feragat etmek, sabr-1 cemil ve Allah korkusunun olması gerektiğini tavsiye etmiştir (Demirci, 2018).

Bir gün bir talebesine yaptı̆̆ konuşmada, kitap okumanın bir ibadet gibi olduğunu, aynı namazda olduğu gibi kitap okuyan kişinin etrafı ile bağını koparması gerektiğini vurgulamış ve size kitap okumayı unutturdular diyerek milletin ve İslâm dünyasının geleceğinin yeni neslin kitap okumasına bağlı olduğunu söylemiştir (Kayadibi, 2018).

\section{Almanya İle Sezgin Arasındaki Dava}

92 yaşındaki Fuat Sezgin, 2017'nin Mayıs ayında, sergilenmek üzere kendisine ait eserleri Frankfurt'tan Türkiye'ye götürürken, Frankfurt Havaalanı'nda sorguya alınmış ve bu bilimsel kitapların, tarihî eser olabileceği zannıla savcılık eserlere el koymuştur. Enstitüsü’nün başkanlık görevinden de el çektirilen Sezgin, gümrükte alıkonulan binlerce kitabın şahsına ait olduğunu beyan etmesine rağmen Almanya'dan çıkışına izin verilmemiştir. Hessen Eyaleti Bilim Bakanlığı da bu kitapların Frankfurt Üniversitesine ait olabileceği düşüncesiyle inceleme başlatmıştır. Savcılık, yapılan soruşturma sonucunda, tarihî eser kaçakçılığı iddiasını kanıtlayacak bir belge olmadığı için soruşturmayı durdurmuş ve kitapların Sezgin'in şahsi birikimi olduğuna karar vermiştir. Ancak buna rağmen Sezgin'e kitapları verilmemiş ve Enstitüdeki odasına girmesine izin verilmemiştir. Havaalanında bu şekilde bir muameleye maruz kalması Sezgin'i çok üzmüştür (Canbolat, 2017).

Soruşturma metnindeki bazı ifadeler bu soruşturmanın siyasi bir yanı olduğunu göstermektedir. Sezgin, 36 senelik vakıf başkanlığında emeklilik maaşı dışında vakıftan maaş almamış, enstitünün arabasına benzini dahi vakfın bütçesinden karşılamamış, vakfın tek bir kuruşunu bile almama konusunda gayretli bir tutuma sahip bir ilim adamıdır. Bugüne kadar bütün eserlerini Almanca yazmış, Almancayı İslâm bilim tarihi konusunda bir "kaynak dil" hâline dönüştürmüş, Almanya'y1 "İslâm bilimleri” alanında bir referans ülke olarak prestij sahibi yapan bir ilim adamına yapılanlar en basit tabiri ile ciddi bir saygısızlık, vefasızlıktır (URL-6, 2018).

Prof. Dr. Fuat Sezgin İslâm Bilim Tarihi Araştırmaları Vakfı (IBTAV) Mütevelli Heyeti Yönetim Kurulu Başkanı Mecit Çetinkaya İBTAV olarak öncelikle Fuat Sezgin'in kitaplarını Almanya'dan Türkiye'ye getirmek istediklerini aktarmıştır. Çetinkaya, "Fuat Sezgin'in Almanya'daki kitaplarının hepsini getirmek bizim en büyük vazifemiz. Hocamız zaten kitaplarını vakfımıza bağışladı. Vakıfta Kültür ve Turizm Bakanlığı'nın söz hakkı var. Yani oradaki kitaplar hem vakıf olarak bizim hem de Kültür ve Turizm Bakanlığı olarak devletin. Dolayısıyla hem hocamızın ruhunu şad etmek için hem de görevimizi yerine getirmek için o kitapları buraya getirmek zorundayız." demiştir (URL-7, 2019). Aynı zamanda devletin zirvesinin de bu sürecin takipçisini olduğunu belirtmek gerekir (URL-8, 2019).

\section{Sonuç}

Mehmet Fuat Sezgin, 94 yaşında iken çok sevdiği İstanbul'da 30 Haziran 2018 tarihinde bir süredir tedavi gördüğü hastanede vefat etmiştir. Ertesi gün cenaze merasimine Cumhurbaşkanı Erdoğan, çok sayıda siyasi ve akademisyen katılmıştır. Sezgin, Fatih Camiinde kılınan cenaze namazının ardından Gülhane Parkında bulunan kendi kurduğu İslâm Bilim ve Teknoloji Tarihi Müzesi yanına defnedilmiştir.

Sezgin, bilim tarihi ve bilim tarihinde Müslümanların yeri konusunda çok önemli çalışmalar yapmış, üstü örtülü bilgileri ortaya çıkarmış, İslâm medeniyeti çocuklarının aşağılık kompleksine girmemeleri için gerekli bilgileri gün yüzüne çıkarmış, dünya çapında tanınırlığ 1 yüksek gerçek bir âlimdir. Kendisine önemli ödüller verilmiştir.

Sezgin bunu yaparken kendi rahatını, hayatını, sağlığını hiçe saymış, büyük ihtimalle ailesine bile yeterince zaman ayırmayıp mütemadiyen çalışmıştır. Gerçekten hayatını ilme vakfetmiş bir şahsiyettir. 
Hansu'nun (2019b: 31) belirttiği gibi bir ilim adamının hayatı da eserleri kadar ilham vericidir. Âlimin hayatını bilmek eserlerini de doğru bir şekilde anlaşı1ır hâle getirir. Fuat Sezgin gibi ilim adamına sahip olan milletler, gelecek kuşaklara kılavuz olması amacıyla onun ismini yaşatmak için çaba sarf eder. Akademi camiasında da Fuat Sezgin'in eserlerinin bilim tarihi açısından ne kadar önemli olduğu konusu ve biyografisi yeterli ilgiyi görememiştir.

Böyle bir şahsiyetin Türkiye'de de yeterince tanınması, tavsiyelerinin hem akademik camiaya hem de diğer insanlara -özellikle gençlere- ulaştırılması, bazı şeylerin başarılabilir olduğu gerçeğini ortaya koyacak ve belki de karamsarlığın yerini çok çalışmak şartıyla ümitli olmak alacaktır. Hiç kuşkusuz bu da Sezgin'in ömrünü vakfettiği İslâm medeniyetinin gelişmesi için faydalı olacaktır.

\section{Kaynaklar}

Canbolat, M. (2017). Almanya, 92 Yaşındaki Türk Bilim Adamına Ayıp Ettiler, http://www.hessen-toplum.com/haber/almanya-92-yasindaki-turk-bilim-adamina-ayipettiler/240, 22.09.2017, (Erişim Tarihi: 22.05.2019).

Demirci, M. (2018). Bir Fuat Sezgin Vard1, https://www.yeniasir.com.tr/ yazarlar/mehmet.demirci/2018/07/05/bir-fuat-sezgin-vardi, 05.07.2018, (Erişim Tarihi: 22.05.2019).

Dere, A. (2018a). Mehmet Fuat Sezgin Hoca'nın Ankara İlahiyat Yılları: Sezgin ve Fakültenin Müşterek Tarihinden Bir Kesit, Ankara Üniversitesi İlahiyat Fakültesi Dergisi, 59(2): 221250.

Dere, A. (2018b). M. Fuat Sezgin (1924-2018): İslâm Tarihine Medeniyet Zaviyesinden Bakan Bir Âlimimizin Ardından Öz Muhasebemiz, Basın Hayatı Dergisi, (50): 41-47.

Fazlıoğlu, İ. (2004). Fuat Sezgin ile Bilim Tarihi Üzerine, Türkiye Araştırmaları Literatür Dergisi, 2(4): 355-370.

Hansu, H. (2019a). Mehmet Fuat Sezgin'in Aile Çevresi ve Türkiye'deki Akademik Serüveni, Ankara Üniversitesi Illahiyat Fakültesi Dergisi, 60(1): 185-205.

Hansu, H. (2019b). Fuat Sezgin'in Ailesi ve Eğitim Hayatının İlk Yılları, Van Yüzüncü Y1l Üniversitesi Uluslararası Prof. Dr. Fuat Sezgin Bilim Tarihi Sempozyumu Sempozyum Kitabı, Ed. Zeki Taştan, İstanbul: Hiperyayın.

Hıdır, Ö. (2018). Bereketli çalışmalara imza atan bir 'İbnü'l Vakt': Fuat Sezgin, https://www.fikriyat.com/tarih/2018/07/02/bereketli-calismalara-imza-atan-bir-ibnul-vaktfuat-sezgin, (Erişim Tarihi: 22.05.2019).

İBTAV. (2019). İlme Adanmış Bir Ömür Prof. Dr. Fuat Sezgin Özgeçmişi, http://www.ibtav.org/sayfa/1/ozgecmisi, (Erişim Tarihi: 22.05.2019).

Kar, A. K. (2018), Fuat Sezgin Hoca'nın ardından..., https://www.dunyabulteni.net/kultursanat/fuat-sezgin-hocanin-ardindan-h425606.html, 13.07.2018, (Erişim Tarihi: 22.05.2019).

Karakaş, A. (2015). 20. Yüzyıl Hadis Eksenli Oksidentalizm Çalışmaları -Fuat Sezgin Örneği-, Yayınlanmamış Doktora Tezi, Çukurova Üniversitesi Sosyal Bilimler Enstitüsü, Adana.

Kayadibi, S. (2018). Fuat Sezgin Hocadan Ne Öğrenmeliyiz?, https://www.milatgazetesi.com/yazarlar/fuat-sezgin-hocadan-ne-ogrenmeliyiz/haber-175005, 06.07.2018, (Erişim Tarihi: 22.05.2019).

Kenan, S. (2003). İslam Dünyasının Duraklama Sebepleri Üzerine Ünlü İlimler Tarihçisi Fuat Sezgini Dinlemek, Değerler Ĕ̌itimi Dergisi, 1(4): 73-98. 
Korkmaz, T. (2009). 20. YY. İslam Bilim Tarihi Çalışmaları George Sarton ve Fuat Sezgin Örneği, Yayınlanmamış Yüksek Lisans Tezi, Marmara Üniversitesi Sosyal Bilimler Enstitüsü, İstanbul.

Macit, A. (2018). Fuat Sezgin Hoca Ardında Güzel Bir Örneklik ve İlmi Miras Bıraktı, https://www.dunyabizim.com/portre/fuat-sezgin-hoca-ardinda-guzel-bir-orneklik-ve-ilmimiras-birakti-h29665.html, 12.08.2018, (Erişim Tarihi: 22.05.2019).

Oğur, Y. (2018). Üniversiteden Atılmış Genç Bir Doçente Veda Ederken, http://www.karar.com/yazarlar/yildiray-ogur/universiteden-atilmis-genc-bir-docente-vedaederken-7364\#, 01.07.2018, (Erişim Tarihi: 22.05.2019).

Özsoy, Ö. (2018). Ömer Özsoy Yazdı: Fuat Sezgin Hoca'nın Ardından, http://www.karar.com/gorusler/omer-ozsoy-yazdi-fuat-sezgin-hocanin-ardindan-902554, 04.07.2018, (Erişim Tarihi: 22.05.2019).

Sezgin, F. (2004). İslam Kültür Dünyasının Bilimler Tarihindeki Yeri, TÜBA Forumu, (29), Ankara.

Sezgin, F. (2016). Amerika'nın Keşfinde Müslümanlar Söyleşi ve Konferans Kitabı, Ed. Kadir Temurçin, SDÜ Yayınları.

Şahin, O. (2013). Darbe Mağduru Profesörler, https://www.dunyabulteni.net/yazar/osmansahin/19373/profdrfuat-sezginin-vefati-darbe-magduru-profesorler, 05.11.2013， (Erişim Tarihi: 22.05.2019).

Şen, H. (2018), Fuat Sezgin'in Miras1, https://www.yenisafak.com/hayat/fuat-sezginin-mirasi3383348, 11.07.2018, (Erişim Tarihi: 22.05.2019).

Tali, S. C. (2019). Bir Ömürlük Külliyat: Geschichte des Arabischen Schrifttums (Arap-İslam Bilimleri Tarihi), Açık Kitap Dergisi, (12): 12-13.

TBMM. (2010). TBMM Albümü 2 (1950-1980), TBMM Basın ve Halkla İlişkiler Müdürlüğü Yayınlar1, (1).

Tuğ, S. (2018). Prof. Dr. Salih Tuğ, Fuat Sezgin'i Anlatıyor: "Bir Duvarla Karşı Karşıya Kaldı", http://www.yorungedergi.com/2018/08/prof-dr-salih-tug-fuat-sezgini-anlatiyor-bir-duvarlakarsi-karsiya-kaldi/?utm_source=sm\&utm_medium=post, 01.08 .2018 , (Erişim Tarihi: 22.05.2019).

Turan, S. (2012). Bilim Tarihi Sohbetleri Fuat Sezgin, İstanbul: Timaş Yayınları.

URL-1. (2016). Prof. Dr. Fuat Sezgin Atatürk Üniversitesi Fahri Doktora Diploma Töreni, https://www.youtube.com/watch?v=qFzqVmXg9GM, (Erişim Tarihi: 22.05.2019).

URL-2. (2016). Sadece Allah'a İnanacaksın Başka Hiçbir Şeye Değil, https://www.haberler.com/sadece-allah-a-inanacaksin-baska-hicbir-seye-degil-8870016haberi/, (Erişim Tarihi: 22.05.2019).

URL-3. (2017). Prof. Dr. Fuat Sezgin' in Özgeçmişi, https://dergipark.org.tr/download/issuefile/5824, (Erişim Tarihi: 22.05.2019).

URL-4. (2019). Hakkında, http://www.ibtav.org/sayfa/6/hakkinda, (Erişim Tarihi: 22.05.2019).

URL-5. (2018). Fuat Sezgin Hoca, http://www.akkalemler.com/fuat-sezgin-hoca-haber-30159, 01.07.2018, (Erişim Tarihi: 22.05.2019).

URL-6. (2018). Fuat Sezgin'in Kitaplarına El Koyan Gözü Dönmüşlük: Frankfurt'ta Neler Oluyor?, https://perspektif.eu/2018/03/01/frankfurtta-fuat-sezgin-kitaplarina-el-konuldu/, 01.03.2018, (Erişim Tarihi: 22.05.2019). 
URL-7. (2019). Fuat Sezgin'in Almanya'daki Kitaplanının Hepsini Getirmek En Büyük Vazifemiz, https://www.timeturk.com/fuat-sezgin-in-almanya-daki-kitaplarinin-hepsinigetirmek-en-buyuk-vazifemiz/haber-1068377, 06.04.2019, (Erişim Tarihi: 22.05.2019).

URL-8. (2019). Cumhurbaşkanının 2019 Prof. Dr. Fuat Sezgin Y1lı Toplantısı'nda Yaptıkları Konuşma, https://www.tccb.gov.tr/konusmalar/353/105482/2019-prof-dr-fuat-sezgin-yilitoplantisi-nda-yaptiklari-konusma, 23.05.2019, (Erişim Tarihi: 22.05.2019).

Yardım, M. N. (2018). Fuat Sezgin, http://www.milatgazetesi.com/fuat-sezginmakale,125366.html, 04.07.2018, (Erişim Tarihi: 22.05.2019).

Yılmaz, İ. (2009). Yitik Hazinenin Kâşsifi Fuat Sezgin, İstanbul: Yitik Hazine Yayınları.

Yolcu, E. (2018). Bu Dünyadan Bir Fuat Sezgin Hoca Geldi, Geçti..., Basın Hayatı Dergisi, (50): 38. 